\title{
Hubungan Konsumsi Sayuran dengan Tekanan Darah Pada Remaja di Tangerang Selatan
}

\author{
Sugiatmi $^{1 *}$, Munaya Fauziah ${ }^{2}$ \\ 1) Program Studi Sarjana Gizi, Fakultas Kedokteran dan Kesehatan, Universitas Muhammadiyah Jakarta \\ 2) Program Studi Kesehatan Masyarakat, Fakultas Kesehatan Masyarakat, Universitas Muhammadiyah Jakarta \\ *atmi.nurdin@gmail.com
}

\begin{abstract}
Background: High blood pressure is a risk factor for cardiovascular diseases. Purposes: This cross sectional study aims to identify the prevalence of prehypertension / hypertension and the relationship between vegetable consumption and blood pressure in adolescent in South Tangerang. Methods: The study lasted for 8 months (January - August 2018) at State Senior High School 6 in Tangerang Selatan Academic Year 2017/2018 of 220 students selected by proportional stratified random sampling. Data on vegetable consumption was collected using the FFQ questionnaire, while blood pressure was measured by trained personnel using digital blood pressure measuring devices and grouped into normal and prehypertension/hypertension. Descriptive data analysis to describe the variables of vegetable consumption and blood pressure, and Chi Square test to examine the relationship of vegetable consumption with prehypertension / hypertension with a significance level (alpha) of 0.05 and a confidence interval (CI) of 95\%. Result: The results of the study were $10.5 \%$ adolescent suffering from prehypertension / hypertension. Conclussion: There was no significant relationship between consumption of vegetables with prehypertension/ hypertension in adolescents ( $p>0.05)$.
\end{abstract}

Keywords: vegetables consumption, blood pressure, prehypertension, hypertension

\begin{abstract}
ABSTRAK
Latar Belakang: Tekanan darah tinggi merupakan faktor risiko timbulnya penyakit kardiovaskular. Tujuan: Penelitian cross sectional ini bertujuan untuk mengidentifikasi prevalensi prehipertensi/hipertensi dan hubungan konsumsi sayuran dengan tekanan darah remaja di Tangerang Selatan. Metode: Penelitian berlangsung selama 8 bulan (Januari Agustus 2018) di SMA Negeri 6 Tangerang Selatan Tahun Ajaran 2017/2018 terhadap 220 siswa yang dipilih secara propotional stratified random sampling. Data konsumsi sayur dikumpulkan menggunakan kuesioner FFQ, sedangkan tekanan darah diukur oleh tenaga terlatih menggunakan alat ukur tekanan darah digital dan dikelompokkan menjadi normal dan prehipertensi/hipertensi. Analisis data deskriptif untuk menggambarkan variabel konsumsi sayuran dan tekanan darah, dan uji Chi Square untuk menguji hubungan konsumsi sayur dengan prehipertensi/hipertensi dengan tingkat kemaknaan (alpha) 0,05 dan selang kepercayaan (CI) 95\%. Hasil: Hasil penelitian 10,5\% ramaja menderita prehipertensi/hipertensi. Kesimpulan: Tidak terdapat hubungan signifikan antara konsumsi sayuran dengan prehipertensi/hipertensi pada remaja $(\mathrm{p}>0,05)$.
\end{abstract}

Kata kunci: konsumsi sayuran, tekanan darah, prehipertensi, hipertensi 


\section{PENDAHULUAN}

Pre-hipertensi dan hipertensi yaitu kondisi tekanan darah sistolik dan diastolik berada pada 120/80 - 139/89 mmHg (pre-hipertensi) dan $140 / 90 \mathrm{mmHg}$ (hipertensi). Jika tidak terkontrol, dalam jangka panjang, pre-hipertensi dapat berlanjut menjadi hipetertensi atau tekanan darah tinggi, yang dan pada akhirnya keduanya menjadi pemicu timbulnya penyakit kardiovaskular (1).

Prevalensi hipertensi di dunia pada remaja dalam kurun waktu 1988 - 2009 diperkirakan $11,2 \%, 13 \%$ remaja laki-laki, dan $9,6 \%$ remaja perempuan, serta prevalensi di negara berkembang lebih tinggi dibanding negara maju (2). Studi pada siswa sekolah di beberapa negara mendapatkan hasil prevalensi tekanan darah tinggi yang berbeda-beda. Prevalensi tekanan darah tinggi pada siswa sekolah menengah di Provinsi Anatolia Tengah Turki, sebesar 4,4\% (3) di Mesir prevalensi prehipertensi dan hipertensi adalah 5,7\% dan 4,0\% (4), dan di Enugu, Nigeria Tenggara, prevalensi prehipertensi 17,3\% dan hipertensi 5,4\% (5).

Di Indonesia, prevalensi hipertensi pada remaja usia 15-17 tahun adalah 5,3 persen (pria 6,0\% dan wanita 4,7\%). Prevalensi hipertensi remaja pedesaan $(5,6 \%)$ lebih tinggi dibanding remaja di daerah perkotaan (5,1\%) (6). Prevalensi hipertensi pada remaja di Pangkalpinang, Provinsi Bangka Belitung $14,17 \%$ pada remaja pria dan 8,33\% pada wanita (7) sedangkan Kota Depok, Provinsi Jawa Barat 42,4\% (8).

Banyak faktor berperan dalam terjadinya hipertensi pada remaja. Konsumsi alkohol, tingkat aktivitas fisik, pola diet, genetik adalah beberapa faktor yang berkaitan dengan hipertensi (9-11) dan prehipertensi (12).

Studi tentang tekanan darah pada remaja di Provinsi Banten masih terbatas dan mengingat hipertensi pada masa remaja adalah faktor risiko untuk hipertensi pada masa dewasa, yang akan meningkatkan angka kematian karena penyakit kardiovaskular, maka tujuan dari penelitian ini untuk mengidentifikasi prevalensi prehipertensi dan hipertensi dan hubungannya dengan konsumsi sayur pada siswa SMA di Tangerang Selatan, Indonesia.

\section{METODE}

Penelitian cross sectional ini dilaksanakan selama 1 tahun (Januari 2018 - Januari 2019) sejak perencanaan hingga penyusunan laporan di SMA Negeri 6 Tangerang Selatan pada seluruh siswa yang aktif pada tahun ajaran 2017/2018. Besar sampel penelitian sebesar 220 siswa dengan teknik propotional stratified random sampling. Sampling dikelompokan menjadi 3 strata, yaitu kelas X, XI dan XII.

Variabel yang dianalisis yaitu konsumsi sayuran dan tekanan darah. Data konsumsi sayuran dikumpulkan melalui wawancara dengan kuesioner FFQ (Food Frequency Questionnaire), kemudian dikelompokkan menjadi sering konsumsi $(\geq 3 \mathrm{x}$ seminggu) dan jarang $(<3 \mathrm{x}$ seminggu). Tekanan darah diukur menggunakan tensimeter digital, selanjutnya dianalisis sebaran datanya. Jika sebaran data tidak noemal, maka tekanan darah dikelompokkan menjadi pre hipertensi/hipertensi $\quad(120 / 80 \quad \mathrm{mmHg}-139 / 89$ $\mathrm{mmHg}$ dan $\geq 140 / 90)$ dan normal $(<120 / 80$ $\mathrm{mmHg}$ ).

Analisis data menggunakan uji chi-square untuk melihat hubungan konsumsi sayuran dengan kejadian prehipertensi. Hubungan dikatakan bermakna jika nilai $\mathrm{p}<0,05$ pada selang kepercayaan (confident interval/CI) $95 \%$.

Penelitian ini telah mendapatkan persetujuan dari komite etik penelitian Fakultas Kedokteran dan Kesehatan Universitas Muhammadiyah Jakarta No. 074/PE/KE/FKK-UMJ/IV/2018. 
HASIL

Tabel 1 Distribusi Responden Berdasarkan Tekanan pada Remaja di Tangerang Selatan Tahun 2018

\begin{tabular}{|c|c|c|}
\hline Tekanan Darah & $\mathbf{n}$ & $(\%)$ \\
\hline Normal & 197 & 89,5 \\
\hline $\begin{array}{l}\text { Pre Hipertensi } \\
\text { Hipertensi }\end{array}$ & 23 & 10,5 \\
\hline Total & 220 & 100 \\
\hline
\end{tabular}

Tabel 1 menunjukkan bahwa 10,5\% responden prehipertensi.

Tabel 2 Gambaran Variabel Hasil Uji Univariat pada Remaja di Tangerang Selatan Tahun 2018

\begin{tabular}{lcc}
\hline \multicolumn{1}{c}{ Variabel } & Frek (n) & $\begin{array}{c}\text { Persentase } \\
(\mathbf{\%})\end{array}$ \\
\hline Jenis Kelamin & & \\
Laki - laki & 87 & 39,5 \\
Perempuan & 133 & 60,5 \\
Konsumsi Sayur & & \\
Sering & 68 & 30,9 \\
Jarang & 152 & 69,1 \\
Total & $\mathbf{2 2 0}$ & $\mathbf{1 0 0}$ \\
\hline
\end{tabular}

Berdasarkan tabel 2 subyek pada penelitian ini lebih banyak pada jenis kelamin perempuan yaitu 133 orang $(60,5 \%)$.

Kemudian untuk variabel konsumsi sayuran, menunjukkan bahwa responden yang jarang konsumsi sayuran 69,1\%, lebih banyak dibandingkan dengan responden yang sering konsumsi sayuran 30,9\%.

Tabel 3 Hubungan Tekanan Darah dengan Konsumsi Sayuran pada Remaja di Tangerang Selatan Tahun 2018 Tekanan Darah

\begin{tabular}{|c|c|c|c|c|}
\hline \multirow{3}{*}{ Variabel } & Teka I & n Darah & \multirow[b]{2}{*}{ Jumlah } & \multirow{3}{*}{$\begin{array}{l}P \text { - } \\
\text { Value }\end{array}$} \\
\hline & Normal & $\begin{array}{c}\text { Pre } \\
\text { hipertensi, } \\
\text { hipertensi }\end{array}$ & & \\
\hline & $\%$ & $\%$ & & \\
\hline
\end{tabular}

\begin{tabular}{lccccccc}
\hline $\begin{array}{l}\text { Konsumsi } \\
\text { Sayuran }\end{array}$ & & & & & & & \\
Sering & 63 & 32 & 5 & 21,7 & 68 & 100 & 0,443 \\
Jarang & 134 & 68 & 18 & 78,3 & 152 & 100 & \\
\hline
\end{tabular}

Pada tabel 3 terlihat responden yang jarang mengonsumsi sayuran lebih banyak prehipertensi (78,3\%) dibandingkan dengan responden yang sering konsumsi sayuran
$(21,7 \%$,$) . Uji statistik menunjukkan hasil tidak$ terdapat hubungan signifikan antara konsumsi sayuran dengan tekanan darah pada remaja $(\mathrm{p}>0,05)$.

\section{PEMBAHASAN}

Proporsi remaja yang mengalami pre-hipertensi pada penelitian ini sebanyak 10,5\%. Angka ini masih lebih rendah dibanding prevalensi prehipertensi pada remaja di beberapa negara yang berkisar antara 12-17\% yang dikemukakan oleh Redwine dan Falkner pada tahun 2012 (12).

Berdasarkan hasil analisis bivariat tidak terdapat hubungan yang bermakna antara konsumsi sayuran dengan pre-hipertensi, artinya baik remaja yang jarang mengonsumsi sayuran maupun remaja yang sering, memiliki risiko yang sama untuk menderita prehipertensi.

Penelitian ini berlawanan dengan penelitian Anwar (2014) dan Diniyah (2018) yang memperoleh hasil terdapat hubungan antara konsumsi sayuran dengan tekanan darah $(13,14)$. Namun demikian, penelitian ini mempunyai hasil yang sama dengan penelitian Prakosa, Wicaksono, dan Damayanti (2014) dan Qanaatun, Astuti (2014) bahwa tidak ada hubungan antara konsumsi sayuran dengan tekanan darah $(15,16)$.

Sayuran mengandung serat yang dapat mencegah hipertensi menurut hasil review oleh Aleixandria dan Miguel (17). Meskipun secara statistik tidak ditemukan hubungan yang signifikan antara konsumsi sayuran dengan tekanan darah, namun konsumsi sayur yang kurang adalah satu dari banyak faktor risiko terjadinya hipertensi yaitu riwayat hipertensi orang tua, intake junkfood, indeks massa tubuh serta konsumsi garam (18). Faktor risiko hipertensi lainnya yaitu konsumsi fast food (19), aktifitas fisik (20) dan sosial ekonomi (21).

Penelitian ini hanya menganalisis hubungan konsumsi sayur dengan tekanan darah, sementara penyebab tekanan darah tinggi (prehipertensi/hipertensi) adalah multifaktor. Hal ini merupakan satu keterbatasan penelitian. 
Keterbatasan lain yaitu pengukuran tekanan darah dilakukan beberapa kali dalam satu waktu, seharusnya beberapa kali dalam waktu yang berbeda. Disain potong lintang juga menjadi keterbatasan penelitian. Oleh karena itu disarankan untuk meneliti dengan disain longitudinal dan penambahan variabel agar hasil penelitian lebih komprehensif.

\section{KESIMPULAN}

Setelah dilakukan penelitian terhadap 220 responden pada remaja di Tangerang Selatan mengenai konsumsi sayuran dengan tekanan darah, maka dapat disimpulkan hasil penelitian yaitu sebanyak 30,9\% responden yang sering konsumsi sayuran dan 69,1\% responden yang jarang konsumsi sayuran. Kemudian sebanyak $89,5 \%$ responden yang memiliki tekanan darah normal dan $10,5 \%$ responden yang memiliki tekanan darah pre hipertensi atau tidak normal.

Dari hasil analisi uji bivariat dapat diketahui bahwa tidak ada hubungan yang bermakna antara konsumsi sayuran dengan tekanan darah pada remaja dengan nilai pvalue $=0,443$.

\section{UCAPAN TERIMAKASIH}

Penulis mengucapkan terima kasih kepada Lembaga Penelitian dan Pengabdian Masyarakat (LPPM) Universitas Muhammadiyah Jakarta atas dukungan dana. Ucapan terima kasih pula kepada Kepala Sekolah SMAN 6 Tangerang Selatan atas kesediaan menjadi tempat penelitian.

\section{KONFLIK KEPENTINGAN}

Penulis menyatakan tidak ada konflik kepentingan dalam penulisan artikel ini.

\section{REFERENSI}

1. Ishikawa $\mathrm{Y}$, Ishikawa J, Ishikawa S, Kario K, Kajii E. Progression from prehypertension to hypertension and risk of cardiovascular disease. J Epidemiol
[Internet]. 2017;27(1):8-13. Available from:

http://dx.doi.org/10.1016/j.je.2016.08.00 1

2. Moraes FDe, Lacerda MB, Moreno LA. Prevalence of High Blood Pressure in 122 , 053 Adolescents: A Systematic Review and Meta-Regression. Medicine (Baltimore). 2014;93(27):1-10.

3. Nur N, Çetinkaya S, Yilmaz A, Ayvaz A, Bulut MO, Sümer H. Prevalence of Hypertension among High School Students in a Middle Anatolian Province of Turkey. J Heal Popul Nutr. 2008;26(1):88-94.

4. Abolfotouh MA, Sallam SA, Mohammed MS, Loutfy AA, Hasab AA. Prevalence of Elevated Blood Pressure and Association with Obesity in Egyptian School Adolescents. Int J Hypertens. 2011;2011(i).

5. Ujunwa FA, Ikefuna AN, Nwokocha ARC, Chinawa JM. Hypertension and prehypertension among adolescents in secondary schools in Enugu, South East Nigeria. Ital J Pediatr. 2013;1-6.

6. Riskesdas. Riset Kesehatan Dasar (RISKESDAS) 2013. Lap Nas 2013. 2013;1-384.

7. Yusrizal M, Indarto D, Akhyar M. Risk of Hypertension in Overweight Adolescents in Pangkalpinang , Indonesia. 2013;273:27-36.

8. Angesti AN, Sartika RAD. Riwayat Hipertensi Keluarga Sebagai Faktor Dominan Hipertensi Pada Remaja Kelas XISMA Sejahtera 1 Depok Tahun 2017. Bul Penelit Kesehat [Internet]. 2018 [cited 2018 Nov 20];46(1). Available from:

http://dx.doi.org/10.22435/bpk.v46i1.71 58.1-10

9. Ewald DR, Haldeman LA. Risk Factors in Adolescent Hypertension. Glob 
Pediatr Heal. 2016;3:1-26.

10. Falkner B. The Childhood Role in Development of Primary Hypertension Bonita. Am J Hypertens. 2018;

11. Rosner B, Prineas RJ, Loggie JMH, Daniels SR, Rosner B, Laboratories C, et al. Blood pressure nomograms for children and adolescents, by height, sex , and age, in the United States.

12. Redwine KM, Falkner B. Progression of prehypertension to hypertension in adolescents. Curr Hypertens Rep [Internet]. 2012 Dec [cited 2018 Nov 20];14(6):619-25. Available from: http://www.ncbi.nlm.nih.gov/pubmed/2 2878957

13. Anwar R. Konsumsi Buah dan Sayur Serta Konsumsi Susu Sebagai Faktor Risiko Terjadinya Hipertensi di Puskesmas S.Parman Kota Banjarmasin. J Skala Kesehat. 2014;5(1).

14. Diniyah N. Hubungan Konsumsi Sayur, Buah dan Asupan Asam Lemak Jenuh dengan Tekanan Darah Pada Lansia di Kota Padang. Universitas Andalas; 2018.

15. Prakosa AM, Wicaksono B, Damayanti EK. Hubungan Frekuensi Konsumsi Buah dan Sayur dengan Hipertensi pada Lansia di Desa Bolon Colomadu Karanganyar. Nexus Kedokt Komunitas. 2014;3(2).

16. Qonaatun I, Asturi H, DCN. Hubungan Riwayat Konsumsi Sayur, Buah, dan Susu dengan Tekanan Darah Pada Lansia Hipertensi yang Mengikuti Posyandu Lansia di Desa Purwomartani, Kalasan, Sleman. Universitas Gajah Mada; 2014.

17. A. Aleixandrea and M. Migue. Dietary fiber and blood pressure. Food Funct. 2016;

18. Khan MI, Patil R, Chauhan N. A Study Of The Risk Factors And The Prevalence
Of Hypertension In The Adolescent School Boys Of Ahmedabad City. J Clin Diagnostic Res. 2010;(May 2014).

19. Zhao Y, Wang L, Xue H, Wang H, Wang Y. Fast food consumption and its associations with obesity and hypertension among children: results from the baseline data of the Childhood Obesity Study in China. BMC Public Health. 2017;1-10.

20. Vale S, Trost SG, Carla R, Abreu S, Mota J. Physical Activity, Obesity Status, and Blood Pressure in Preschool Children. J Pediatr. 2015;167:98-102.

21. Julia $M$, Weissenbruch $M$ van, HA Delemarre Waal van de, Surjono A. The influence of socioeconomic status on blood pressure of Indonesian prepubertal children. J Hum Hypertens. 2006;546-8. 